\title{
Variations in Trim5a and Cyclophilin A genes among HIV-1 elite controllers and non controllers in Uganda: a laboratory-based cross-sectional study
}

Sharon Bright Amanya 1,2, Brian Nyiro², Francis Waswa ${ }^{2}$, Bonniface Obura ${ }^{1}$, Rebecca Nakaziba1, Eva Nabulime ${ }^{3}$, Ashaba Fred Katabazi ${ }^{2}$, Rose Nabatanzi ${ }^{2}$, Alice Bayiyana ${ }^{2}$, Gerald Mboowa ${ }^{2,4}$, Alex Kayongo ${ }^{5}$, Misaki Wayengera ${ }^{2}$ and Obondo J. Sande $2^{2^{*}(0)}$

\begin{abstract}
Background: Tripartite Motif Containing 5 alpha (TRIM5a), a restriction factor produced ubiquitously in cells and tissues of the body plays an important role in the immune response against HIV. TRIM5a targets the HIV capsid for proteosomal destruction. Cyclophilin A, an intracellular protein has also been reported to influence HIV infectivity in a cell-specific manner. Accordingly, variations in TRIM5a and Cyclophilin A genes have been documented to influence HIV-1 disease progression. However, these variations have not been documented among Elite controllers in Uganda and whether they play a role in viral suppression remains largely undocumented. Our study focused on identifying the variations in TRIM5a and Cyclophilin A genes among HIV-1 Elite controllers and non-controllers in Uganda.
\end{abstract}

Results: From the sequence analysis, the rs $10838525 \mathrm{G}$ > A mutation in exon 2 of TRIM5a was only found among elite controllers (30\%) while the rs3824949 in the 5'UTR was seen among $25 \%$ of the non-controllers. In the Cyclophilin A promoter, rs 6850 was seen among $62.5 \%$ of the non-controllers and only among $10 \%$ elite controllers. Furthermore, rs 17860048 in the Cyclophillin A promoter was predominantly seen among elite controllers (30\%) and 12.5\% noncontrollers. From gene expression analysis, we noted that the respective genes were generally elevated among elite controllers, however, this difference was not statistically significant (TRIM5a p=0.6095; Cyclophilin A $p=0.6389$ ).

Conclusion: Variations in TRIM5a and Cyclophillin A promoter may influence HIV viral suppression. The rs 10838525 SNP in TRIM5a may contribute to viral suppression among HIV-1 elite controllers. The rs6850 in the cyclophillin A gene may be responsible for HIV-1 rapid progression among HIV-1 non-controllers. These SNPs should be investigated mechanistically to determine their precise role in HIV-1 viral suppression.

\section{Background}

Currently, 36.7 million people are living with HIV of which $70 \%$ are from the WHO African region [1]. To date, there is no documented cure, rather, HIV infected

*Correspondence: ojsande@gmail.com

2 Department of Immunology and Molecular Biology, Makerere University College of Health Sciences, Kampala, Uganda

Full list of author information is available at the end of the article individuals are enrolled in lifelong Anti-retroviral Treatment (ART). Whereas ART enables them to live long healthy lives [1], there are concerns such as; viral latency, drug side effects and, resistance associated with longterm ART [2]. This creates a need to study host immune factors, restriction factors that enable host cells to resist HIV replication.

Restriction factors, dominantly acting proteins that function in a cell-autonomous manner to suppress HIV 
viral replication at distinct stages have been reported to influence HIV susceptibility and disease progression [3]. These include; Tripartite Motif-containing $5 \alpha$ (TRIM $5 \alpha$ ), Apolipoprotein $B$ messenger RNA editing enzyme catalytic polypeptide-like 3 (APOBEC3), Tetherin/bone marrow stromal cell antigen (BST2) [3], Myxovirus resistance protein $2(\mathrm{MxB})$, and Sterile $\alpha$ motif domain-HD domaincontaining protein 1 (SAMDH1) [4]. TRIM5 $\alpha$, a member of the tripartite motif-containing family of proteins restricts HIV by interfering with viral capsid uncoating hence terminating downstream processes that facilitate HIV genome integration [5]. It is also implicated in the modulation of innate immune signaling via nuclear factor kappaB (NF-kB) and activator protein 1 (AP-1) leading to the production of inflammatory cytokines such as interleukin-2 (IL-2) \& interferon-gamma (IFN- $\gamma$ ), along with various cell surface markers [6]. Recent studies have reported that polymorphism in the human TRIM $5 \alpha$ gene affects susceptibility to and progression of HIV infection. For example, R136Q single nucleotide polymorphism has been associated with resistance to HIV [7] while the defective H43Y mutation is reported to increase progress in HIV infection within the population [8]. Another intracellullar protein, Cyclophilin A (CypA) has been reported to influence HIV infectivity in a cell specific manner [9]. Consequently, polymorphisms in CypA gene have also been documented to influence susceptibility to HIV-1 infection [10].

The presence of HIV elite controllers, individuals who maintain undetectable viral load for more than 5 years without anti-retroviral therapy is proof that there are unique genetic, immunologic and virologic mechanisms that are protective to these people and would, therefore, be critical in developing effective host-directed therapies. In Uganda, Elite controllers constitute $0.26 \%$ [11] of the 1300,000 adults living with HIV in Uganda [12]. Exploring variations in TRIM5 $\alpha$ and CypA genes among HIV-1 elite controllers is therefore essential to identify protective mutations that can be used as target molecular markers for host-directed therapy and screening tools for targeted anti-HIV-1 therapy. In this study, we report on the variations in TRIM5 $\alpha$ and CypA genes as well as their expression patterns among HIV-1 elite and non-controllers in Uganda.

\section{Results}

\section{Participant characteristics}

This was a cross-sectional study conducted among 18 HIV-1 chronically infected individuals. These included 10 elite controllers [HIV plasma viral load $<50$ viral RNA (vRNA) copies $\mathrm{ml}^{-1}$ ] and 8 non-controllers (ART controlled) whose demographic characteristics are summarised in Table 1.

\section{TRIM5a and Cyclophilin A gene variations}

Considerable evidence suggests that variations in genes of intrinsic cellular defense against HIV influence HIV-1 disease progression $[13,14]$. TRIM $5 \alpha$, one of the genes of intrinsic defense against HIV-1 and particularly it's exon 2 that encodes for the ring domain that has E3 ubiquitin ligase activity and is important for the flexibility of TRIM proteins [15]. We sequenced the gene from the $5^{\prime} \mathrm{UTR}$ through exon 2 to intron 2. Previously stored PBMCs were thawed and then DNA extracted using Qiagen Blood Genomic DNA Kit (QIAamp DNA kit; Qiagen, Inc., Valencia, California, USA). The DNA was PCR amplified and then sequenced. Results indicate that rs10838525 single nucleotide polymorphisms (SNPs) were predominant among elite controllers (30\%) while rs3824949 was more among non-controllers (25\%) (Table 2; Fig. 1). Because SNPs in a coding region can affect protein function, we used the gomNAD browser to determine the effect of these mutations on protein function. The rs10838525 SNP in exon 2 was noted to cause R136Q amino acid change that is synonymous (Table 2; Fig. 1)

Additionally, the promoter region for Peptidyl Prolyl Isomerase A (PPIA) gene which encodes for Cyclophilin A protein was also sequenced and SNPs characterized. We found that elite controllers had more rs17860048 SNP (30\%) while rs6850 SNP dominated among noncontrollers (62.5\%) (Table 3; Fig. 2).

\section{TRIM5 $a$ and Cyclophilin A gene expression}

To determine the effect of these mutations on gene expression, CD4+T cells were isolated using human $\mathrm{CD}^{+} \mathrm{T}$ cell enrichment magnetic kit following the manufacturer's instructions (StemCell Technologies, Vancouver, Canada). The CD4+T cells were assessed for purity by flow cytometry using the BD FACS CANTO II (BD Bioscience, Franklin Lakes, New Jersey, USA), and then stimulated with plate coated Anti-CD3 and soluble AntiCD28 monoclonal antibodies for $48 \mathrm{~h}$. The cells were confirmed for activation by flow cytometry prior to gene expression studies (Fig. 3).

Total RNA was extracted using the Quick-RNA ${ }^{\mathrm{TM}}$ Whole Blood kit (Zymo Research, California, U.S.A) and mRNA levels of TRIM5 $\alpha$ and Cyclophilin $A$ was measured by RT qPCR. The respective genes were more expressed among HIV-1 elite controllers, however, the difference was not statistically significant (Fig. 4).

\section{Discussion}

Our findings suggest that variations in TRIM5 $\alpha$ and the regulatory region of Cyclophilin A genes influence HIV-1 viremic control and consequently HIV disease 
Table 1 Demographic and clinical characteristics of study participants

\begin{tabular}{|c|c|c|c|c|c|c|}
\hline Age & Sex & CD4 count $^{a}$ & $\begin{array}{l}\text { Duration in Care } \\
\text { (Years) }\end{array}$ & VL & Months between VLs & $\mathrm{BMI}^{\mathrm{b}}$ \\
\hline \multicolumn{7}{|c|}{ Elite controllers } \\
\hline 53 & $\mathrm{~F}$ & 1245 & 10 & Undetectable & 8 & 33.9 \\
\hline 38 & $\mathrm{~F}$ & 919 & 9 & Undetectable & 12 & 18.9 \\
\hline 36 & $\mathrm{~F}$ & 1188 & 7 & Undetectable & 8 & 38.5 \\
\hline 56 & M & 833 & 7 & Undetectable & 9 & 17.2 \\
\hline 42 & $\mathrm{~F}$ & 909 & 5 & Undetectable & 9 & 31.8 \\
\hline 30 & $\mathrm{~F}$ & 1050 & 5 & Undetectable & 10 & 29.3 \\
\hline 37 & $\mathrm{~F}$ & 728 & 6 & Undetectable & 9 & 23.9 \\
\hline 40 & $\mathrm{~F}$ & 994 & 10 & Undetectable & 9 & 32.3 \\
\hline 41 & M & 778 & 9 & Undetectable & 12 & 25.2 \\
\hline 37 & $\mathrm{~F}$ & 1063 & 6 & Undetectable & 8 & 26.1 \\
\hline \multicolumn{7}{|c|}{ Non-controllers } \\
\hline 40 & M & 920 & 6 & 10,500 & 6 & 27.2 \\
\hline 41 & $\mathrm{~F}$ & 1192 & 6 & 2840 & 10 & 37.5 \\
\hline 40 & $\mathrm{~F}$ & 940 & 5 & 10,800 & 15 & 26.3 \\
\hline 29 & $\mathrm{~F}$ & 747 & 5 & 14,800 & 8 & - \\
\hline 43 & F & 781 & 8 & 2310 & 8 & 32.7 \\
\hline 38 & F & 589 & 5 & 75,100 & 10 & 21.4 \\
\hline 42 & F & 1021 & 8 & 5250 & 6 & 21.3 \\
\hline 41 & $\mathrm{~F}$ & 852 & 10 & 2850 & 7 & 30.2 \\
\hline
\end{tabular}

a Baseline CD4 at time of recruitment

b BMI denotes body mass index

Table 2 TRIM 5a exon 2 SNPs among HIV-1 elite controllers and non-controllers

\begin{tabular}{|c|c|c|c|c|}
\hline SNP & Chromosome Position & dbNo. & Aminoacid Change & Percentage (\%) \\
\hline \multicolumn{5}{|c|}{ Elite controllers $(n=10)$} \\
\hline $5839 G>G A$ & 11:5701001 & rs10838525 & R136Q & 30 \\
\hline $5376 \mathrm{C}>\mathrm{CT}$ & $11: 5701464$ & Novel SNP & $5^{\prime} \cup T R$ & 10 \\
\hline \multicolumn{5}{|c|}{ Non controllers $(n=8)$} \\
\hline $5431 C>C G$ & 11:5701409 & rs3824949 & $5^{\prime} \cup T R$ & 25 \\
\hline $5428 \mathrm{C}>\mathrm{CG}$ & 11:5701412 & Novel SNP & 5'UTR & 12.5 \\
\hline $5879 G>G C$ & 11:5700961 & Novel SNP & Intron & 12.5 \\
\hline $5880 \mathrm{delC}$ & 11:5700960 & Novel SNP & Intron & 12.5 \\
\hline
\end{tabular}

progression. We have identified rs10838525 SNP in exon 2 of TRIM $5 \alpha$ which is predominated among HIV-1 elite controllers (30\%) while rs3824949 in the $5^{\prime} \mathrm{UTR}$ of TRIM5 $\alpha$ is concentrated among non-controllers (25\%). The rs10838525 SNP in exon 2 results in the amino acid change from Arginine to Glutamine at codon 136 (R136Q). This has been reported to confer protection against HIV for high-risk individuals and slow progress of HIV disease for those infected [7, 13]. In the present study, we report a high frequency of rs10838525 among elite controllers (30\%). These findings are comparable to the $32 \%$ documented among HIV negative healthy controls in a previous study conducted to identify the distribution of TRIM $5 \alpha$ mutations among Brazilian HIV positive individuals and HIV negative healthy controls [16]. Taken together, these findings imply that the rs1083852 confers protection against HIV disease progression. In the present study, the rs3824949 in the $5^{\prime} \mathrm{UTR}$ of TRIM $5 \alpha$ was seen more among HIV-1 non-controllers (25\%). The $5^{\prime} \mathrm{UTR}$ region is known for anchoring binding sites for proteins that regulate translation in response to molecular signals [17], therefore a mutation in this region 


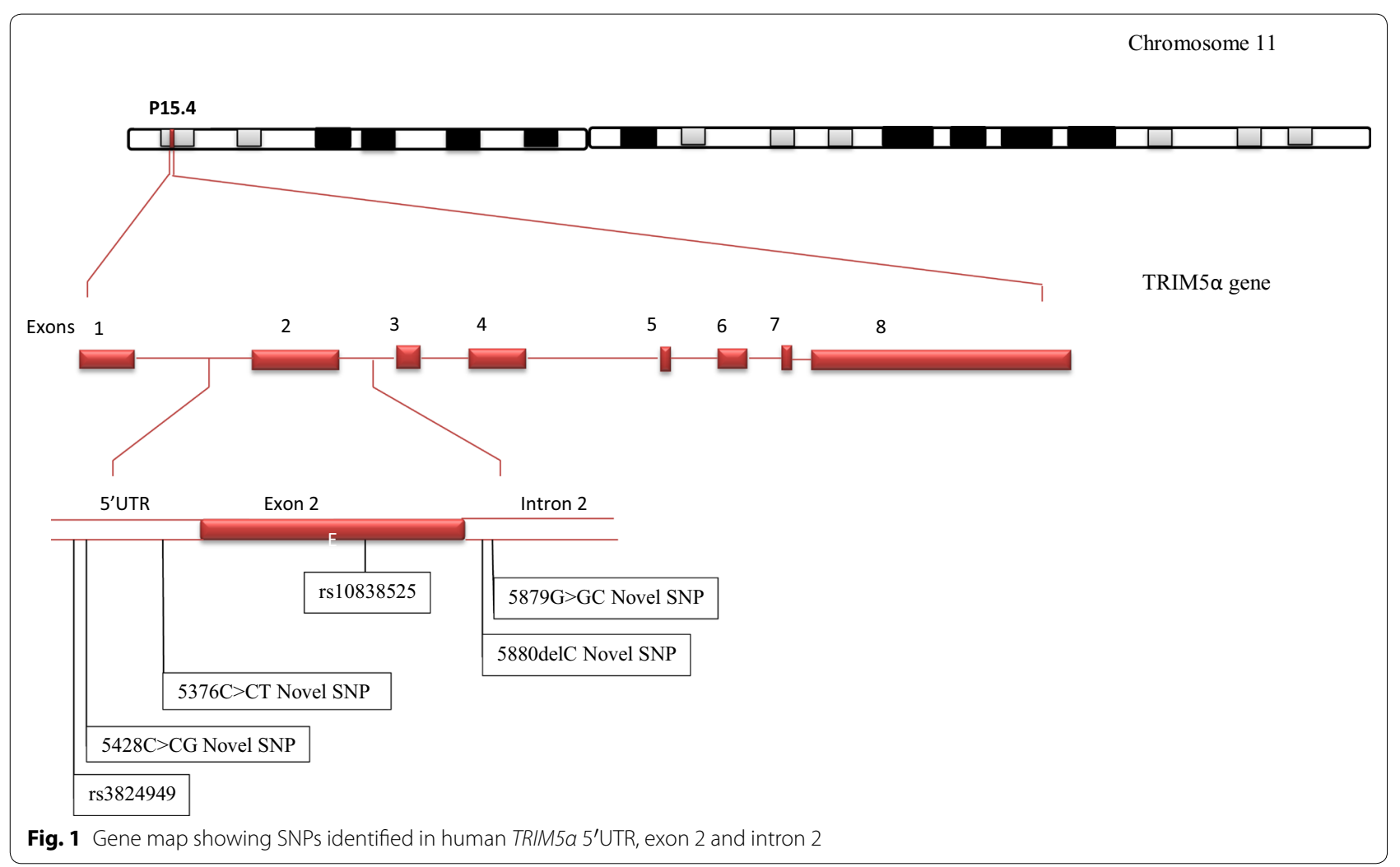

Table 3 Cyclophilin A SNPs among HIV-1 elite controllers and non-controllers

\begin{tabular}{llll}
\hline SNP & \multicolumn{1}{c}{ Chromosome Position } & dbNo. & Percentage (\%) \\
\hline Elite controllers $(n=10)$ & & \\
$520 C>C T$ & $7: 44836260$ & rs17860048 & 30 \\
$574 A>A G$ & $7: 44836314$ & rs6850 & 10 \\
435A > AC & $7: 44836175$ & Novel SNP & 20 \\
Non controllers $(n=8)$ & & \\
574A $>$ AG & $7: 44836314$ & rs6850 & 62.5 \\
520C > CT & $7: 44836260$ & rs17860048 & 12.5 \\
886dupG & $7: 44836626$ & Novel SNP & 12.5 \\
\hline
\end{tabular}

could affect TRIM5a gene expression, eventually influencing HIV disease progression. Sun et al. in their study among acutely and chronically HIV-infected patients showed that rs3824949GG genotype was associated with rapid disease progression while those with the $\mathrm{CC}$ genotype had reduced risk for rapid disease progression [18]. The CG genotype, however, had no significant association with rapid disease progression [18]. Similar findings were reported among HIV-1 positive Caucasian homosexual men enrolled in the Amsterdam cohort Studies (ACS) [14]. The role of rs3824949 genotype has also been observed in other diseases, with the GG genotype being associated with rapid antiretroviral treatment response compared to the CG and CC genotypes among Hepatitis C infected individuals $[19,20]$. Since the CG genotype was seen among non-controllers in our study, it may not be of any significance in HIV disease progression.

In the current study, we found rs6850 SNP in the regulatory region of Peptidyl Prolyl Isomerase A (PPIA) gene that encodes for Cyclophilin A protein, to be more concentrated among HIV-1 non-controllers (62.5\%). The presence of rs6850 SNP possibly increases Cyclophillin A expression which in turn increases HIV infectivity. Previous studies show that rs6850 is significantly associated with high HIV viral loads and lower CD4+T cell counts [21-23]. Moreover, the minor allele rs6850G found among $62.5 \%$ of the non-controllers has been previously reported to increase Cyclophillin A mRNA levels [21], thus implying that rs6850 SNP could increase HIV infectivity and disease progression by altering Cyclophillin $\mathrm{A}$ plasma levels. This is supported by a study among diabetes patients that demonstrated that rs6850 was associated with increased plasma levels of Cyclophillin A, and an increased likelihood of cardiovascular diseases among patients with or without diabetes [24]. Additionally, Rath et al. also reported that rs6850 was associated with recurrent myocardial infarction among patients 


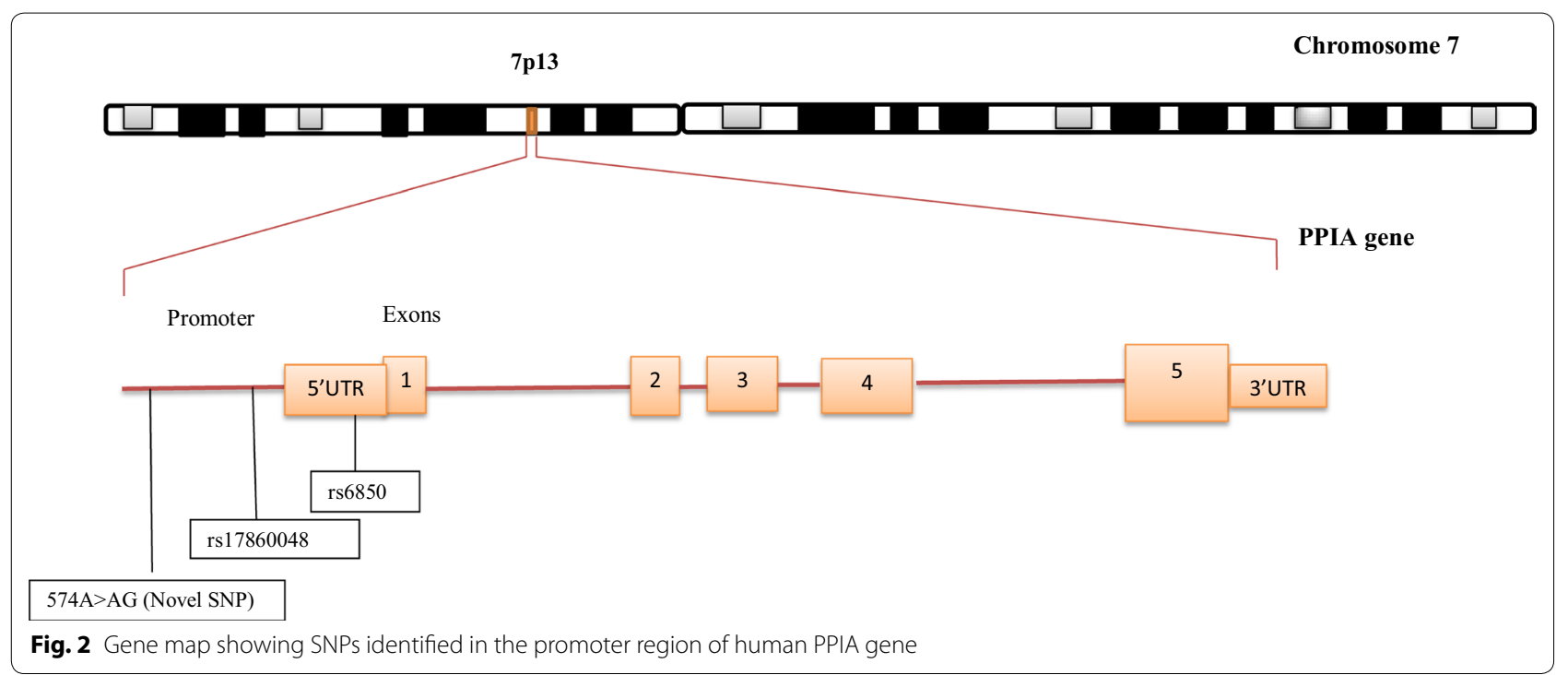

with symptomatic coronary artery disease [25]. Taken together, these findings could imply that rs6850 increases Cyclophillin A protein expression that affects signaling and protein folding thus promoting susceptibility to various disease pathologies including HIV infectivity and disease progression among non-controllers. Another SNP, rs17860048 was found to be more prevalent among elite controllers; however, its role in HIV disease progression has not been reported.

Furthermore, we wanted to understand whether the expression of the respective genes varied between HIV-1 elite controllers and non-controllers. Our study findings show that TRIM5 $\alpha$ and Cyclophilin A are highly expressed among elite controllers compared to the noncontrollers. However, this difference was not statistically significant (TRIM5 $\alpha \mathrm{p}=0.6095$ and CypA $\mathrm{p}=0.6389$ ). These findings agree with those from previous studies (40). Vigneault et al. (2011) in their transcriptional profiling study of $\mathrm{CD}^{+}{ }^{+} \mathrm{T}$ Cells among HIV-1 patients noted that gene transcripts known to be involved in intrinsic cellular defense against retroviruses, such as the TRIM, tetherin/BST2, cyclophilin A, and other genes were not differentially expressed among elite controllers compared to ART controlled HIV positive individuals [26]. Nonetheless, other studies have found a correlation between elevated expression of Cyp A and HIV disease progression [27]. These findings could mean that the viral suppression effect exhibited by elite controllers could be due to other mechanisms, not necessarily increased expression of the respective genes. However the small sample size in our study may have limited us in producing statistically significant results. Another limitation of this study was the gender imbalance, we cannot rule out the possible effect of gender on these findings. Future studies should consider a more gender balanced approach in investigating the role of variations in TRIM5a and Cylophillin A genes among HIV-1 elite controllers.

\section{Conclusion}

In summary, our work reveals key SNPs within genes of intrinsic cellular defense against HIV that potentially play a role in HIV-1 viral suppression. Within the exon 2 of the TRIM $5 \alpha$ gene, rs 10838525 was only seen among elite controllers while rs6850 within the regulatory region of Cyclophillin A gene was seen predominantly among non-controllers $(62.5 \%)$. These findings imply that variations in TRIM5 $\alpha$ and cyclophilin A genes influence HIV-1 viral suppression. Furthermore, there was slightly higher TRIM5 $\alpha$ and cyclophilin A gene expression among elite controllers as opposed to non-controllers although this difference was not statistically significant. This could imply that the elevated levels of genes involved in cellular intrinsic protective mechanisms against HIV may play a role in viral suppression exhibited by elite controllers and this effect needs to be investigated further with a large cohort of participants.

\section{Methods}

The aim, research design, and setting of the study

The study aimed at characterizing the variations in TRIM5 $\alpha$ and CypA genes among Ugandan HIV-1 elite controllers and non-controllers.

A laboratory-based crossectional study was conducted utilizing PBMC samples from the Elite study cohort. The Elite study was conducted between 2016 and 2018 and its aim was to examine the role of host genes in $\mathrm{T}$ cell 


\section{Lymphocytes}

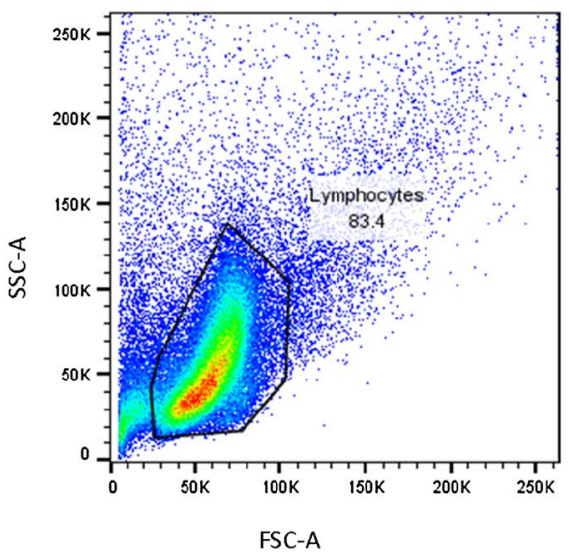

2. Live

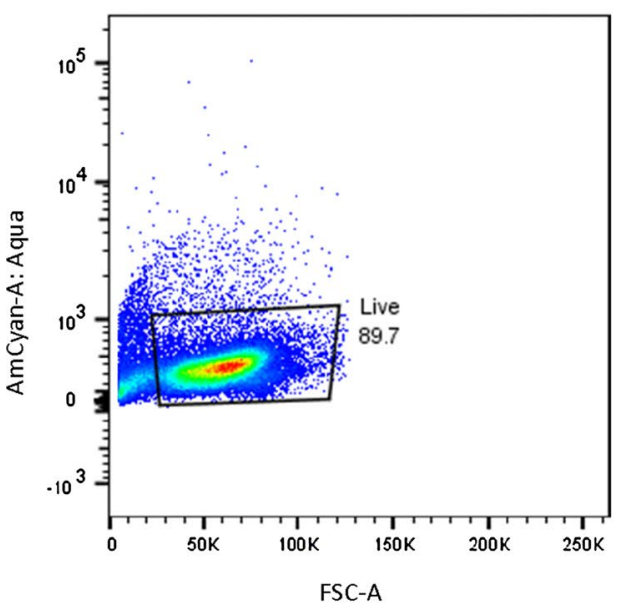

5. $\mathrm{CD}^{+}$

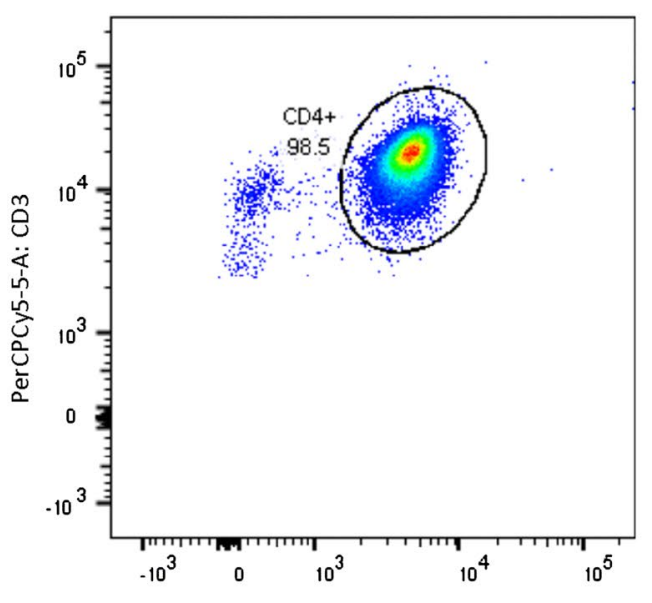

APC: $\mathrm{CD} 4$

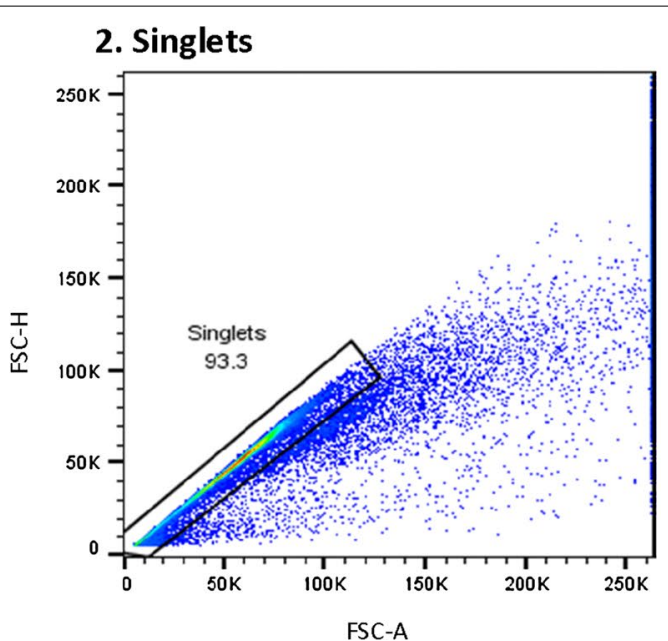

3. $\mathrm{CD}^{+}$

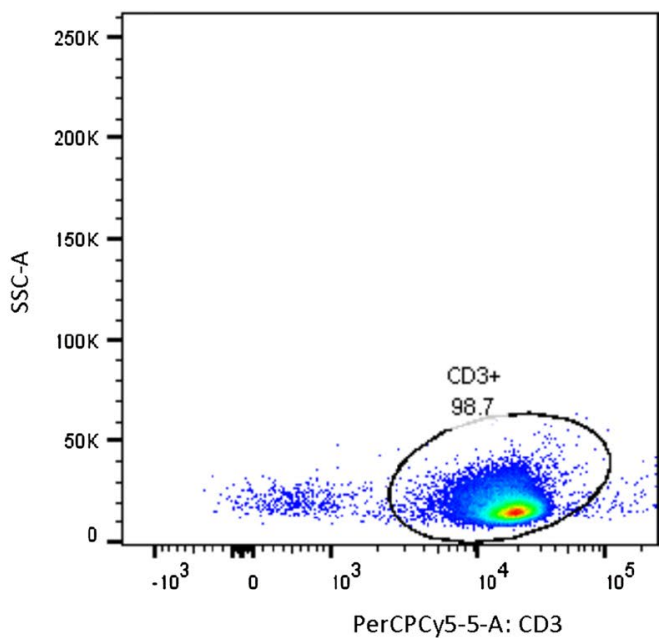

6. $\mathrm{CD}^{+} 5^{+}$

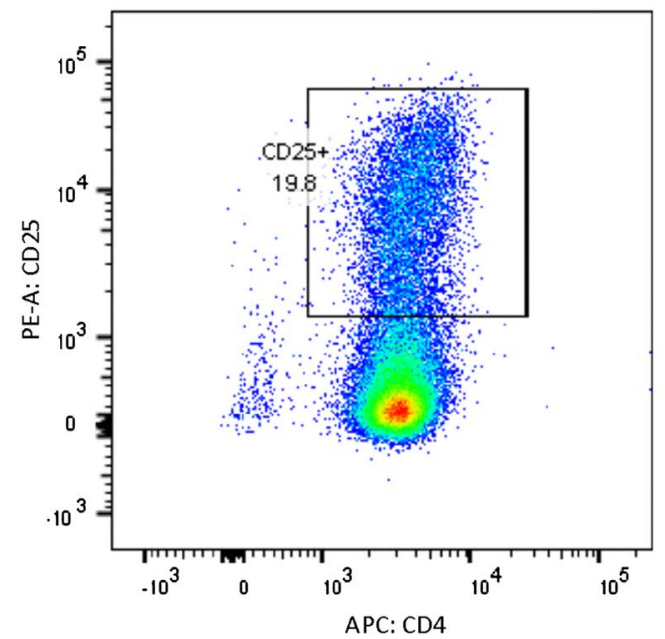

Fig. 3 Cell activation prior to gene expression studies: A sequential gating strategy was used to confirm cell activation after $48 \mathrm{~h}$ of culture prior to gene expression studies 


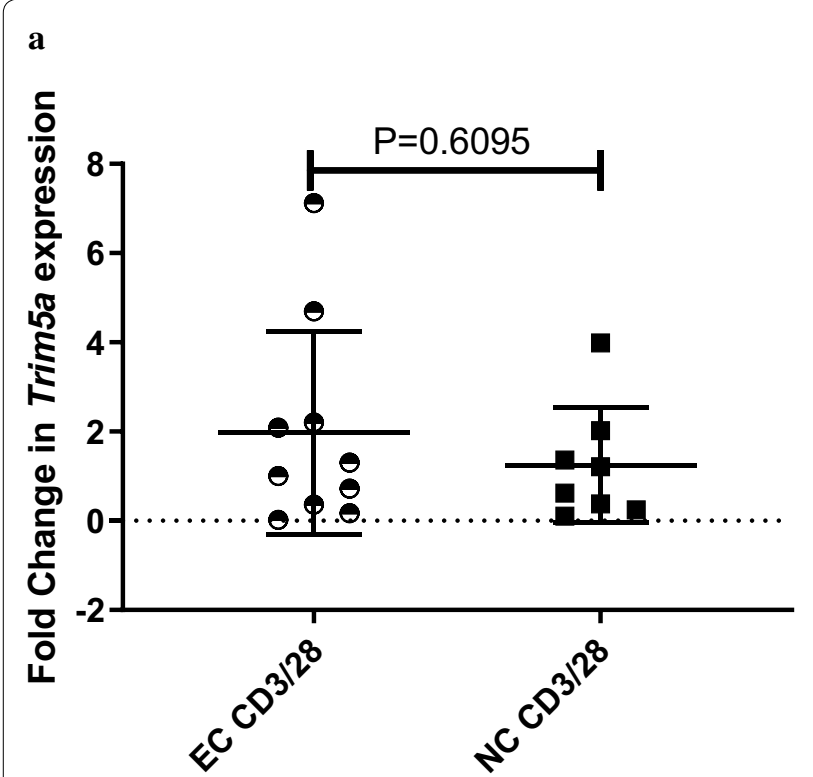

Fig. 4 Graph A shows the difference in expression for TRIM5a gene is not statistically significant between elite controllers (EC) and non-controllers (NC) $(p=0.6095)$. Similarly, Graph B shows Cyclophillin A gene expression is more among elite controllers, but the difference is not statistically significant $(p=0.6369)$

resistance to HIV among Elite and Viremic controllers in Uganda. The Elite study recruited participants from Makerere University Joint Aids Program (MJAP) ISS clinic.

The laboratory experiments were conducted at Makerere University College of Health Sciences, Molecular and Immunology Laboratories. Other assays were conducted at the Center For AIDS Research (CFAR) laboratory, Joint Clinical Research Center in Kampala, Uganda.

\section{Participant characteristics}

The study utilized PBMC samples from two [2] patient groups, namely; a) HIV-1 elite controllers (undetectable viral load with $>5$ years in care without ART) and b) noncontrollers (HIV infected individuals well controlled on ART).

Elite controllers were selected basing on the following criteria; HIV infected individuals $>18$ years old, have been confirmed to be HIV infected by HIV RNA PCR using Abbort real-time HIV-1 Assay (Abbott Molecular, USA), ART naïve for $\geq 5$ years with $\mathrm{CD} 4^{+} \mathrm{T}$ cell count of $\geq 500$ cells $/ \mathrm{ml}$, have a viral load of $<50$ copies $/ \mathrm{ml}$, have a hemoglobin concentration $>10 \mathrm{~g} / \mathrm{dl}$ and are able to give written informed consent. Non-controllers were defined as HIV-1 infected individuals who are well controlled on ART. Being well controlled on ART meant $\mathrm{CD} 4^{+} \mathrm{T}$ cell count of $>500$ cells $/ \mathrm{ml}$ and no opportunistic infections. All those with active opportunistic infections e.g. Pneumocystis jiroveci pneumonia (PJP), Tuberculosis (TB), platelets $<50$ and Bleeding disorders were excluded from the study.

\section{Laboratory methods \\ Treatment of PBMCs before storage}

PBMCs isolated using Ficoll gradient centrifugation were washed with PBS and centrifuged at $1700 \mathrm{rpm}$ for $5 \mathrm{~min}$. The supernatant was discarded, and the pellet re-suspended in $40 \mathrm{ml}$ PBS, and the wash step repeated twice. The cells were stained with trypan blue and counted using an automatic cell counter (Invitrogen, Carlsbad, California, USA). Those with viability $\geq 96 \%$ were prepared for storage. The cells were re-suspended in $1 \mathrm{ml}$ of freeze media, then $0.5 \mathrm{ml}$ of each sample aliquoted and stored in 2 cryovials. The cryovials were immediately placed in Mr. Frosty storage container (Thermo Fisher Scientific, Waltham, Massachusetts, USA), then stored overnight in a freezer at $-80{ }^{\circ} \mathrm{C}$. The cryovials were transferred to liquid nitrogen for storage the following day until use.

\section{Sample processing and thawing}

PBMCs were retrieved from liquid nitrogen and immediately thawed in a water bath set at $37^{\circ} \mathrm{C}$. Thereafter, they were transferred into $10 \mathrm{ml}$ of $\mathrm{R}-10$ media and then centrifuged at $1500 \mathrm{rpm}$ for $10 \mathrm{~min}$. The supernatant was decanted, and the pellet resuspended in $5 \mathrm{ml} \mathrm{R}-10$ media (10\% FBS, 1\% Pen-strep, 1\% L-Glutamine, 1\% Hepes Buffer, and RPMI) for counting. The cells were stained 
with trypan blue and counted using an automatic cell counter (Invitrogen, Carlsbad, California, USA). $1 \mathrm{ml}$ of the sample was removed for DNA extraction.

\section{CD4+ $T$ cell isolation}

The thawed PBMCS were subjected to $\mathrm{CD}^{+} \mathrm{T}$ cell isolation using human $\mathrm{CD}^{+} \mathrm{T}$ cell enrichment magnetic kit following the manufacturer's instructions (StemCell Technologies, Vancouver, Canada). The isolated CD4 ${ }^{+} \mathrm{T}$ cells were washed in $1 \mathrm{ml}$ PBS, centrifuged at $1500 \mathrm{rpm}$ for $10 \mathrm{~min}$. These were resuspended in $2 \mathrm{ml} \mathrm{R}-10$ media, stained for counting with trypan blue and then incubated at $37^{\circ} \mathrm{C}$ on a 24 well plate for $2 \mathrm{~h}$ in a $\mathrm{CO}_{2}$ incubator. The cells were also stained for purity using anti-CD3, and anti-CD4 and ran on a BD FACS Canto II (BD Biosciences, Franklin Lakes, New Jersey, USA).

\section{CD4+T cell Stimulation}

A 96-well plate coated with $100 \mu \mathrm{l}$ of $5 \mu \mathrm{g} / \mathrm{ml}$ of AntiCD3 (eBioscience Clone CD28.2) was incubated at $37^{\circ} \mathrm{C}$ for $2 \mathrm{~h}$ in a $\mathrm{CO}_{2}$ incubator. For negative control wells, $100 \mu \mathrm{l}$ of PBS was added. After the $2 \mathrm{~h}$ incubation, the plate was bloated. In each well, 100,000 cells from the sample were added and topped up with R-10 media containing $5 \mu \mathrm{g} / \mathrm{ml}$ of anti-CD28 (eBioscience clone OKT3) to make $200 \mu \mathrm{l}$ per well. For negative control wells, $110 \mu \mathrm{l}$ of PBS was added. The plate was incubated at $37^{\circ} \mathrm{C}$ for $48 \mathrm{~h}$ in a $\mathrm{CO}_{2}$ incubator.

\section{RNA extraction}

RNA was extracted using Quick-RNA ${ }^{\mathrm{TM}}$ Whole Blood kit (Zymo Research, California, U.S.A) following the manufacturer's instructions. The $\mathrm{CD}^{+}{ }^{+} \mathrm{T}$ cell samples previously suspended in RNAlater (Sigma-Aldrich, St. Louis, Missouri, US) were centrifuged at $10.000 \mathrm{~g}$ for $1 \mathrm{~min}$ and then decanted. The pellet was re-suspended in $300 \mu \mathrm{l}$ of DNA/RNA Shield ${ }^{\mathrm{TM}}$ then $30 \mu \mathrm{l}$ PK digestion buffer and $15 \mu \mathrm{l}$ Proteinase $\mathrm{K}$ added to the sample and mixed well. The mixture was incubated at $55{ }^{\circ} \mathrm{C}$ for $30 \mathrm{~min}$. After incubation, the sample was vortexed and then centrifuged at $16,000 \mathrm{~g}$ for $2 \mathrm{~min}$. The supernatant was transferred into RNase-free eppendoff tubes. To the supernatant, $350 \mu \mathrm{l}$ of RNA recovery buffer was added and mixed well, transferred into a Zymo-Spin ${ }^{\mathrm{TM}}$ IIICG Column in a Collection Tube and centrifuged at $16,000 \mathrm{~g}$ for $30 \mathrm{~s}$. To the filtrate, $700 \mu \mathrm{l}$ of $100 \%$ ethanol was added and mixed well. The mixture was transferred into a Zymo-Spin ${ }^{\mathrm{TM}}$ IC Column in a Collection Tube, centrifuged at $16,000 \mathrm{~g}$ for $30 \mathrm{~s}$ and then the filtrate discarded. This was followed by DNase treatment to remove extra traces of DNA in the column. To achieve this, the column was washed with $400 \mu \mathrm{l}$ RNA wash buffer and centrifuged at $16,000 \mathrm{~g}$ for $30 \mathrm{~s}$ and thereafter the filtrate discarded. A Mixture of
$5 \mu \mathrm{l}$ DNase and $35 \mu \mathrm{l}$ DNA digestion buffer was made and added directly to the column matrix. The column was incubated at room temperature for $15 \mathrm{~min}$. After DNase treatment, $400 \mu \mathrm{l}$ RNA prep buffer was added to the column and centrifuged at $16,000 \mathrm{~g}$ for $30 \mathrm{~s}$. The filtrate was discarded, and $700 \mu \mathrm{l}$ RNA wash buffer added to the column and centrifuged at $16,000 \mathrm{~g}$ for $30 \mathrm{~s}$. The filtrate was discarded, $400 \mu \mathrm{l}$ RNA wash buffer added and then centrifuged for $2 \mathrm{~min}$ at $16,000 \mathrm{~g}$. The column was then transferred into an RNase free eppendorf tube, thereafter, $15 \mu \mathrm{l}$ DNase/RNase-free water added directly onto the column matrix to elute RNA. The eluted RNA was quantified by Qubit 4 Fluorometer (Invitrogen, Carlsbad, CA, USA). The RNA was then immediately stored at $-80{ }^{\circ} \mathrm{C}$ prior to downstream processes.

\section{CDNA synthesis and reverse transcription $P C R$}

Extracted RNA was subjected to cDNA synthesis and real-time PCR using QuantiTect Probe RT-PCR Kit (Qiagen Inc., Valencia, CA, USA) as described in the manufacturer's instructions. A $50 \mu \mathrm{l}$ reaction volume was used for the PCR. Primers and probes used were obtained from a previous study [28] and are summarized in Table 4. For each gene to be measured, separate master mix containing; a) $25 \mu \mathrm{l} 2 \times$ QuantiTect Probe RT-PCR Master Mix (HotStarTaq ${ }^{\circledR}$ DNA Polymerase, QuantiTect Probe RT-PCR Buffer, dNTP mix, including dUTP, $\mathrm{ROX}^{\mathrm{TM}}$ passive reference dye, and $\left.\mathrm{MgCl} 2\right)$, b) $2 \mu \mathrm{l}$ of each of the forward and reverse primers, c) $1 \mu$ of the probe, d) $0.5 \mu \mathrm{l}$ of the QuantiTect RT Mix, and e) $12 \mu \mathrm{l}$ of the RNase free water. In every PCR tube, $42 \mu \mathrm{l}$ of the master mix was added, and then $4 \mu \mathrm{l}$ of RNA template added in 3 tubes containing master mix of the 3 respective genes namely; GAPDH (reference gene), Cyclophilin A (target gene), and TRIM5 $\alpha$ (target gene). For each of the genes, a negative control was added in each of the experiments containing mastermix and PCR water but

\begin{tabular}{ll} 
Table 4 Primers and probes used in reverse transcriptase \\
PCR to quantify expression of TRIM5a, CypA and GAPDH \\
\hline Protein & Primers and probes(Tamra) \\
\hline TRIM5a F & 5'-TGCCTCTGACACTGACTAAGAAGATG \\
TRIM5a R & 5'-GGGCTAAGGACTCATTCATTGG \\
TRIM5a Probe & 5'-(6-Fam)AAGCTTTTCAACAGCCTTTCTATATCATCG \\
& TGTATA \\
CypA F & 5'-GGCCGCGTCTCCTTTGA \\
CypA R & 5'-AATCCTTTCTCTCCAGTGCTCAGA \\
Probe & (6-Fam)TGCAGACAAGGTCCCAAAGACAGCAG \\
GAPDH F & 5'-ACCCCTGGCCAAGGTCATC \\
GAPDH R & 5'-AGGGGCCATCCACAGTCTTC \\
Probe & 5'-(6-Fam)AGGACTCATGACCACAGTCCATGCCA \\
\hline
\end{tabular}


no RNA template added. The PCR tubes were loaded into the Rotor gene Q real-time PCR machine (Quiagen Inc, Valencia, California, USA) and PCR set using the following conditions; reverse transcription (cDNA synthesis) at $55{ }^{\circ} \mathrm{C}$ for $30 \mathrm{~min}$, PCR initial activation at $95{ }^{\circ} \mathrm{C}$ for $15 \mathrm{~min}$, followed by 45 cycles of denaturation at $94{ }^{\circ} \mathrm{C}$ for $15 \mathrm{~s}$, and combined annealing and extension $60{ }^{\circ} \mathrm{C}$ for $60 \mathrm{~s}$. Ct values for each gene were obtained and analyzed using the delta CT relative quantification method to determine the fold change in gene expression.

\section{DNA extraction}

DNA was extracted using the Qiagen Blood Genomic DNA Kit (QIAamp DNA kit; Qiagen, Inc., Valencia, California, USA) in accordance with the manufacturer's instructions as used in the previous studies [29]. $20 \mu \mathrm{l}$ of Qiagen Protease was pipetted into the bottom of a $1.5 \mathrm{ml}$ microcentrifuge tube, then $200 \mu \mathrm{l}$ sample added. $200 \mu \mathrm{l}$ Buffer AL was then added to the sample and mixed by pulse-vortexing for $15 \mathrm{~s}$. The mixture was incubated at $56{ }^{\circ} \mathrm{C}$ for $10 \mathrm{~min}$ and centrifuged to remove drops from the inside of the lid. $200 \mu \mathrm{l}$ ethanol (96-100\%) were added to the PBMCs and mixed again by pulse-vortexing for $15 \mathrm{~s}$. After mixing, the tube was again centrifuged to remove drops from the inside of the lid. The reaction mixture was applied to the QIAamp Mini column, centrifuged for $6000 \mathrm{~g}$ for $1 \mathrm{~min}$ and the filtrate discarded. The column was placed in a clean $2 \mathrm{ml}$ collection tube. $500 \mu \mathrm{l}$ of Buffer AW1 was then added to the QIAamp Mini column and centrifuged at $6000 \mathrm{~g}$ for $1 \mathrm{~min}$. The tube containing the filtrate was discarded and the column placed in a new clean collection tube. $500 \mu \mathrm{l}$ Buffer AW2 was also added, centrifuged at 20,000 $\mathrm{g}$ for $3 \mathrm{~min}$ and the tube containing filtrate discarded. The column was placed in a new collection tube, centrifuged at 20,000 $\mathrm{g}$ for $1 \mathrm{~min}$ and the tube containing filtrate discarded. The QIAamp Mini column was then placed in a clean $1.5 \mathrm{ml}$ microcentrifuge tube and $200 \mu \mathrm{l}$ Buffer AE added. The mixture was incubated at room temperature for $1 \mathrm{~min}$ and then centrifuged at $6000 \mathrm{~g}$ for $1 \mathrm{~min}$ to elute DNA. The extracted DNA was stored at $-80^{\circ} \mathrm{C}$ prior to PCR amplification.

\section{PCR amplification}

\section{Exon 2 of TRIM5a gene}

PCR amplification of TRIM5 $\alpha$ gene $\left(5^{\prime} \mathrm{UTR}\right.$, exon 2 \& intron 2) was carried out with 35 cycles of denaturation at $94{ }^{\circ} \mathrm{C}$ for $30 \mathrm{~s}$, annealing at $58^{\circ} \mathrm{C}$ for $30 \mathrm{~s}$, and extension at $68^{\circ} \mathrm{C}$ for $45 \mathrm{~s}$ using SuperScript III platinum Taq polymerase (Invitrogen, Carlsbad, California, USA) in the presence of $2 \times$ reaction buffer, $5 \mathrm{mM} \mathrm{MgCl}$ with primers summarized in Table 5 as described in a similar study [13].
Table 5 Primers for amplification of of TRIM5a gene

\begin{tabular}{ll}
\hline Location & Primer \\
\hline $\mathrm{F}$ & TGCAGGGATCTGTGAACAAG \\
$\mathrm{R}$ & CCATCTGGTCCCATTTTCTG \\
\hline
\end{tabular}

Table 6 Primers used for amplification of Cyclophillin A promoter

\begin{tabular}{lc}
\hline Location & Primer \\
\hline C1604G-F & GCACTGTCA \\
& CTCTGG \\
& CGAAGT \\
P4H-R & CGCAGAC \\
& GCCGAGCAC \\
& GTGCGT \\
& CGGACA \\
& GGAC \\
\hline
\end{tabular}

\section{Cyclophillin A gene promoter}

PCR amplification of the Cyclophilin A gene was carried out with 40 cycles of denaturing at $95^{\circ} \mathrm{C}$ for $30 \mathrm{~s}$, annealing at $65^{\circ} \mathrm{C}$ for $45 \mathrm{~s}$, and extension at $68^{\circ} \mathrm{C}$ for $45 \mathrm{~s}$ using SuperScript III platinum Taq polymerase (Invitrogen, Carlsbad, California, USA) in the presence of $2 \mathrm{X}$ reaction buffer, $5 \mathrm{mM} \mathrm{MgCl}$ with primers summarized in Table 6 as described in a similar study [30].

\section{PCR Clean up}

From all samples positive on gel electrophoresis that have a single band, $10 \mu \mathrm{l}$ was aliquoted into a new PCR tube and $2 \mu \mathrm{l}$ of ExosapIT reagent added. The tubes were then transferred into a thermocycler (Applied Biosystems, California, United States) and ran under the following conditions: $37{ }^{\circ} \mathrm{C}$ for $45 \mathrm{~min}, 80^{\circ} \mathrm{C}$ for $45 \mathrm{~min}$ and held at $4{ }^{\circ} \mathrm{C}$. Thereafter, PCR products were stored at $-20{ }^{\circ} \mathrm{C}$ prior to Sanger sequencing.

\section{Sanger sequencing Cycle sequencing}

Sequencing mastermix was prepared including $0.5 \mu \mathrm{l}$ of big dye terminator, $1.75 \mu \mathrm{l}$ of $5 \mathrm{X}$ sequencing buffer, $2.5 \mu \mathrm{l}$ of primer, and $4.25 \mu \mathrm{l}$ of water for the $10 \mu \mathrm{l}$ reaction. $9 \mu \mathrm{l}$ of the master mix was added into each plate well and $1 \mu \mathrm{l}$ of the sample was then added. The plate was loaded in a SimpliAmp thermocycler (Applied Biosystems, California, United States), and ran under the following conditions; $96{ }^{\circ} \mathrm{C}$ for $1 \mathrm{~min}$, then 30 cycles of $96{ }^{\circ} \mathrm{C}$ for $20 \mathrm{~s}$, $50{ }^{\circ} \mathrm{C}$ for $20 \mathrm{~s}$, and $60{ }^{\circ} \mathrm{C}$ for $4 \mathrm{~min}$. Thereafter, the plate was held at $4{ }^{\circ} \mathrm{C}$ awaiting cleaning. 


\section{Clean up}

Ethanol precipitation was done as follows. The 96-well sequencing reaction plate was removed from the SimpliAmp thermocycler and the plate centrifuged at $1000 \mathrm{rpm}$ for one minute without cooling. To each well, $2.5 \mu \mathrm{l}$ of $125 \mathrm{mM}$ EDTA was added, followed by $1.0 \mu \mathrm{l}$ $3 \mathrm{M}$ Sodium Acetate pH 5.2 and then $30 \mu \mathrm{l}$ of Absolute Ethanol to each well. The plate was sealed and vortexed briefly for $5 \mathrm{~s}$, then incubated at room temperature for $30 \mathrm{~min}$ to precipitate the extension products. The plate was centrifuged at $3000 \mathrm{rpm}$ for $60 \mathrm{~min}$, at $4{ }^{\circ} \mathrm{C}$. The plate cover was then removed, and the plate inverted on a paper towel placed in the microplate carrier assembly in the plate centrifuge. The plate was centrifuge at $500 \mathrm{rpm}$ for one minute. $100 \mu \mathrm{l}$ of $70 \%$ absolute Ethanol were added to each plate well and the plate heated at $90{ }^{\circ} \mathrm{C}$ for $1 \mathrm{~min}$ in a SimpliAmp thermocycler (Applied Biosystems, California, United States).

\section{Electrophoresis}

$10 \mu \mathrm{l}$ of $0.1 \mathrm{mM}$ EDTA was added to each sample well and the plate sealed. The plate was vortexed for $5 \mathrm{~s}$ and then centrifuged at $1000 \mathrm{rpm}$ for one minute without cooling to bring down the contents of the wells. The samples were then ready to run in the 3730xl DNA analyzer (Applied Biosystems, California, United States).

\section{Data analysis}

Data was entered in excel and exported to GraphPad prism 8 for analysis. CD $4^{+} \mathrm{T}$ cells were analyzed on an 8-laser FACS Canto II (BD Bioscience, Franklin Lakes, New Jersey, USA). Approximately 50,000 events were recorded per sample. In addition, antibody capture beads (BD Bioscience, Franklin Lakes, New Jersey, USA) were used for compensation and prepared individually by separate staining of all the antibodies used in the experiment. FlowJo X 10.6 (Treestar, Oregon, USA) was used for gating analysis. For mRNA quantification, relative quantification using the obtained $\mathrm{CT}$ value was done using the delta $C T$ method. Statistical differences between the different groups were determined using the unpaired $t$ test in Graph pad prism v8. Sequence analysis was done using Mutation Surveyor software to identify SNPs in the respective genes. Frequencies and percentages of the SNPs were determined. SNPs in the coding region were analysed using the gno$\mathrm{mAD}$ to determine the amino-acid change.

\section{Abbreviations}

ART: Antiretroviral therapy; Cyclophilin A: CypA; DNA: Deoxyribonucleic acid; HIV: Human immunodeficiency virus; MJAP: Makerere University Joint Aids Program; PBMC: Peripheral blood mononuclear cells; PCR: Polymerase chain reaction; RNA: Ribonucleic acid; SNP: Single nucleotide polymorphism; TRIM5a: Tripartite Motif containing 5 alpha; WHO: World Health Organization.

\section{Acknowledgements}

We would like to extend our sincere gratitude to Dr. David Patrick Ketete, Head of Department Immunology and Molecular Biology for his technical guidance during the research as well as Ms. Geraldine Nalwadda, Department of Immunology and Molecular Biology for her administrative support. We thank the staff of Immunology and molecular laboratories at Makerere University as well as the Center for AIDS Research laboratories at the Joint Clinical Research Center, Kampala Uganda for their technical input during the research.

\section{Authors' contribution}

There are 13 authors in this manuscript namely; SBA, BN, FW, BO, RN, EN, AFK, $R N, A B, A K, G M, M W$, and OJS. SBA conceived the concept and developed it under the supervision of MW and OJS. SBA, BN,FW, AK, BO,RN, AB, RN and OJS conducted the cell isolation, culture and flow cytometry experiments of the study. SBA, BN, EN, AFK, GM, and MW conducted the DNA sequencing and RNA expression experiments and contributed to bioinformatics analysis. SBA made the final draft of the manuscript and all authors proofread and approved for publication. All authors read and approved the final manuscript.

\section{Funding}

This work was done as partial fulfillment for the award of a degree of Master of Science in Immunology and Clinical Microbiology to SBA. SBA is a MITHU fellow and the research was funded by NIH Fogarty, Grant No. D43TW010319 (MITHU PI: Henry Boom). Part of the work was funded by the African Centre of Cxcellence in Materials, Product development, and Nanotechnology (ACE_ MAPRONANO) Project ID: P151847/IDA 5797-UG. OJS is a NURTURE fellow under NIH grant D43TW010132 (PI: Nelson Sewankambo).

\section{Availability of data and materials}

The datasets used and/or analyzed during the current study are available from the corresponding author on reasonable request.

\section{Ethics approval and consent to participate}

Ethical clearance was obtained from the Makerere University School of Biomedical Sciences Research and Ethics Committee. A waiver of consent was obtained before samples were used.

\section{Consent for publication}

Not applicable.

\section{Competing interests}

The authors declare that they have no competing interests.

\section{Author details \\ ${ }^{1}$ Faculty of Health Sciences, Lira University, Lira, Uganda. ${ }^{2}$ Department of Immunology and Molecular Biology, Makerere University College of Health Sciences, Kampala, Uganda. ${ }^{3}$ Center for AIDS Research (CFAR) Lab, Joint Clinical Research Center, Kampala, Uganda. ${ }^{4}$ The African Center of Excellence in Bioinformatics and Data Intensive Sciences, the Infectious Diseases Institute, McKinnell Knowledge Centre, Makerere University, Kampala, Uganda. ${ }^{5}$ Mak- erere University Lung Institute, Kampala, Uganda.}

Received: 5 May 2020 Accepted: 27 June 2020

Published online: 06 July 2020

\section{References}

1. WHO. HIV/AIDS: World Health Organization; 2017 http://www.who.int/ mediacentre/factsheets/fs360/en/.

2. Pham HT, Mesplede T. The latest evidence for possible HIV-1 curative strategies. Drugs in context. 2018;7:212522.

3. Malim MH, Bieniasz PD. HIV restriction factors and mechanisms of evasion. Cold Spring Harbor Perspect Med. 2012;2(5):a006940.

4. Jia X, Zhao Q, Xiong Y. HIV suppression by host restriction factors and viral immune evasion. Curr Opin Struct Biol. 2015;31:106-14. 
5. Lukic Z, Hausmann S, Sebastian S, Rucci J, Sastri J, Robia SL, et al. TRIM5a associates with proteasomal subunits in cells while in complex with HIV-1 virions. Retrovirology. 2011;8(1):93.

6. Kawai T, Akira S. Regulation of innate immune signalling pathways by the tripartite motif (TRIM) family proteins. EMBO Mol Med. 2011;3(9):513-27.

7. Price H, Lacap P, Tuff J, Wachihi C, Kimani J, Ball TB, et al. A Trim5alpha exon 2 polymorphism is associated with protection from HIV-1 infection in Pumwani sexworker cohort. AIDS (London, England). 2010;24(12):1813.

8. Sawyer SL, Wu LI, Akey JM, Emerman M, Malik HS. High-frequency persistence of an impaired allele of the retroviral defense gene TRIM5a in humans. Curr Biol. 2006;16(1):95-100.

9. Burse M, Shi J, Aiken C. Cyclophilin A potentiates TRIM5a inhibition of HIV-1 nuclear import without promoting TRIM5a binding to the viral capsid. PLoS ONE. 2017;12(8):e0182298.

10. Rits MA, Van Dort KA, Kootstra NA. Polymorphisms in the regulatory region of the Cyclophilin A gene influence the susceptibility for HIV-1 infection. PLoS ONE. 2008;3(12):e3975.

11. Kayongo A, Gonzalo-Gil E, Gümüşgöz E, Niwaha AJ, Semitala F, Kalyesubula R, et al. Identification of Elite and Viremic Controllers from a Large Urban HIV Ambulatory Center in Kampala, Uganda. J Acquir Immune Defic Syndr. 2018;79(3):394.

12. UNAIDS. HIV and AIDS estimates: UNAIDS Uganda Country Office; 2020. https://www.unaids.org/en/regionscountries/countries/uganda. Accessed 8 June 2020.

13. Javanbakht H, An P, Gold B, Petersen DC, O'Huigin C, Nelson GW, et al. Effects of human TRIM5a polymorphisms on antiretroviral function and susceptibility to human immunodeficiency virus infection. Virology. 2006;354(1):15-27.

14. Van Manen D, Rits MA, Beugeling C, Van Dort K, Schuitemaker H, Kootstra NA. The effect of Trim5 polymorphisms on the clinical course of HIV-1 infection. PLoS Pathog. 2008;4(2):e18.

15. Grütter MG, Luban J. TRIM5 structure, HIV-1 capsid recognition, and innate immune signaling. Current opinion in virology. 2012;2(2):142-50.

16. Da Silva RC, Coelho AVC, Arraes LC, Brandão LAC, Crovella S, Guimarães RL. TRIM5 gene polymorphisms in HIV-1-infected patients and healthy controls from Northeastern Brazil. Immunol Res. 2016;64(5-6):1237-42.

17. Chatterjee S, Pal JK. Role of $5^{\prime}$-and $3^{\prime}$-untranslated regions of mRNAs in human diseases. Biol Cell. 2009;101(5):251-62.

18. Sun X, Li W, Liu W, Wang R, Li Q, Wu H. Genetic polymorphisms of Trim5a are associated with disease progression in acutely and chronically HIVinfected patients. Int J Clin Exp Med. 2015;8(9):16199.

19. Mobasheri S, Irani N, Sepahi AA, Sakhaee F, Jamnani FR, Vaziri F, et al. Evaluation of TRIM5 and TRIM22 polymorphisms on treatment responses in Iranian patients with chronic hepatitis C virus infection. Gene. 2018;676:95-100.

20. Medrano LM, Rallón N, Berenguer J, Jiménez-Sousa MA, Soriano V, Aldámiz-Echevarria T, et al. Relationship of TRIM5 and TRIM22 polymorphisms with liver disease and HCV clearance after antiviral therapy in HIV/ HCV coinfected patients. J Transl Med. 2016;14(1):257.

21. Madlala $P$, Singh $R$, An $P$, Werner L, Mlisana K, Karim SSA, et al. Association of polymorphisms in the regulatory region of the cyclophilin A gene (PPIA) with gene expression and HIV/AIDS disease progression. J Acquir Immune Defic Syndr. 2016;72(5):465.

22. Bleiber G, May M, Martinez R, Meylan P, Ott J, Beckmann JS, et al. Use of a combined ex vivo/in vivo population approach for screening of human genes involved in the human immunodeficiency virus type 1 life cycle for variants influencing disease progression. J Virol. 2005;79(20):12674-80.

23. von Hahn T, Ciesek S. Cyclophilin polymorphism and virus infection. Curr Opin Virol. 2015;14:47-9.

24. Vinitha A, Kutty VR, Vivekanand A, Reshmi G, Divya G, Sumi S, et al. PPIA rs6850: a > G single-nucleotide polymorphism is associated with raised plasma cyclophilin A levels in patients with coronary artery disease. Mol Cell Biochem. 2016:412(1-2):259-68.

25. Rath D, von Ungern-Sternberg S, Heinzmann D, Sigle M, Monzien M, Horstmann $\mathrm{K}$, et al. Platelet surface expression of cyclophilin A is associated with increased mortality in patients with symptomatic coronary artery disease. J Thromb Haemost. 2020;18(1):234-42.

26. Vigneault F, Woods M, Buzon MJ, Li C, Pereyra F, Crosby SD, et al. Transcriptional profiling of CD4 T cells identifies distinct subgroups of HIV-1 elite controllers. J Virol. 2011:85(6):3015-9.

27. Braaten D, Luban J. Cyclophilin A regulates HIV-1 infectivity, as demonstrated by gene targeting in human T cells. EMBO J. 2001;20(6):1300-9.

28. Matsuoka S, Dam E, Lecossier D, Clavel F, Hance AJ. Modulation of HIV-1 infectivity and cyclophilin A-dependence by Gag sequence and target cell type. Retrovirology. 2009;6(1):21.

29. Singh H, Samani D, Ghate MV, Gangakhedkar RR. Impact of cellular restriction gene (TRIM5a, BST-2) polymorphisms on the acquisition of HIV-1 and disease progression. J Gene Med. 2018;20(2-3):e3004.

30. An P, Wang LH, Hutcheson-Dilks H, Nelson G, Donfield S, Goedert JJ, et al. Regulatory polymorphisms in the cyclophilin A gene, PPIA, accelerate progression to AIDS. PLoS Pathog. 2007;3(6):e88.

\section{Publisher's Note}

Springer Nature remains neutral with regard to jurisdictional claims in published maps and institutional affiliations.
Ready to submit your research? Choose BMC and benefit from:

- fast, convenient online submission

- thorough peer review by experienced researchers in your field

- rapid publication on acceptance

- support for research data, including large and complex data types

- gold Open Access which fosters wider collaboration and increased citations

- maximum visibility for your research: over 100M website views per year

At BMC, research is always in progress.

Learn more biomedcentral.com/submissions 